\title{
The Lowland Patayan in the southern U.S. Southwest: Tracking vessel movement through ceramic compositional analyses
}

\author{
Margaret E. Beck ${ }^{\mathrm{a}, *}$, Jeffrey R. Ferguson ${ }^{\mathrm{b}}$ \\ a Department of Anthropology, University of Iowa, 114 Macbride Hall, Iowa City, Iowa, 52242, United States \\ ${ }^{\mathrm{b}}$ Archaeometry Laboratory, University of Missouri Research Reactor, 1513 Research Park Drive, Columbia, MO 65211, United States
}

\section{A R T I C L E I N F O}

\section{Article history:}

Received 9 November 2015

Received in revised form 28 April 2016

Accepted 3 May 2016

Available online 15 May 2016

\section{Keywords:}

US Southwest

Ceramics

Lower Colorado Buff Ware

Hohokam Buff Ware

Patayan

Compositional analysis

Neutron activation analysis

\begin{abstract}
A B S T R A C T
We evaluate possible source areas for the ancestral Yuman (Lowland Patayan) ceramics at Las Colinas (AZ T:12:10 [ASM]) in Arizona's Phoenix Basin approximately 1000-1200 CE, using neutron activation analysis and other compositional data from southern California, the eastern Papaguería in Arizona, and Las Colinas. Our study finds no evidence of ceramic vessels moving long distances between these different regions occupied by the Lowland Patayan, although vessels may have been moved over shorter distances. The Patayan ceramics at Las Colinas were not made there, but could have been made within a several-days walk of Las Colinas using an undocumented source of phyllite for temper.
\end{abstract}

(c) 2016 Elsevier Ltd. All rights reserved.

\section{Introduction}

During late prehistory, Native Americans throughout the U.S. Southwest engaged in widespread interactions, exchanges, conflicts, and population movements (Hill et al., 2004; Mills et al., 2013; Mills et al., 2015). These regional alliances, economies, and demographic shifts are perhaps best known from the archaeological record of village farmers, but smaller groups of mobile horticulturalists and foragers also participated. Here we address movement and exchange among ancestral Yuman (Lowland Patayan) groups in the southern Southwest using ceramic compositional data from southern California, the Gila Bend, Arizona area of the eastern Papaguería, and the site of Las Colinas (AZ T:12:10 [ASM]) north of the Salt River in Arizona's Phoenix Basin. Although other evidence suggests that Lowland Patayan people moved eastward across the Papaguería into the Phoenix Basin some time after $1000 \mathrm{CE}$, our study finds no evidence of ceramic vessels moving long distances between different regions occupied by the Lowland Patayan. Some vessels moved shorter distances, such as the phyllite-tempered Patayan ceramics recovered from Las Colinas.

\footnotetext{
* Corresponding author.

E-mail addresses: margaret-beck@uiowa.edu (M.E. Beck), fergusonje@missouri.edu (J.R. Ferguson)
}

\subsection{Background}

This research is set in and around the Papaguería (Fig. 1)-a portion of the Sonoran Desert in southwestern Arizona and northwestern Sonora lacking substantial water sources except those along its borders (the Gila River to the north, the Gulf of California to the south, the Colorado River to the west, and the Santa Cruz River to the east). Between 600 $1300 \mathrm{CE}$, villages of Uto-Aztecan (Hohokam) farmers dominated the Lower Gila River, along the northern border of the Papaguería, to the east of Gila Bend, Arizona.

The Hohokam villages along the Lower Gila were similar to those along the Middle Gila in many respects, with ball courts, canal irrigation of agricultural fields, and production of Hohokam Buff Ware ceramics during the Colonial and Sedentary periods, approximately 7501150 CE (Abbott, 2000a; Doyel, 2000; Lindauer, 1988; Shaul and Andresen, 1989; Shaul and Hill, 1998; Teague, 1981; Wasley and Johnson, 1965). After 700 CE, nearby ancestral Yuman (Lowland Patayan) groups interacted with the Hohokam, with the Patayan making ceramics using the same riverine clays as Hohokam potters and transporting vessels at least $50 \mathrm{~km}$ into the desert interior (Beck and Neff, 2007; Beck et al., 2012). After 1000-1100 CE, the Patayan may have moved into traditional Hohokam territory to the east, living within or between Hohokam communities along the Middle Gila, Salt, and Santa Cruz Rivers.

These ancestral Yuman neighbors were considerably less sedentary and less reliant on agriculture than were the Hohokam. Recognized 


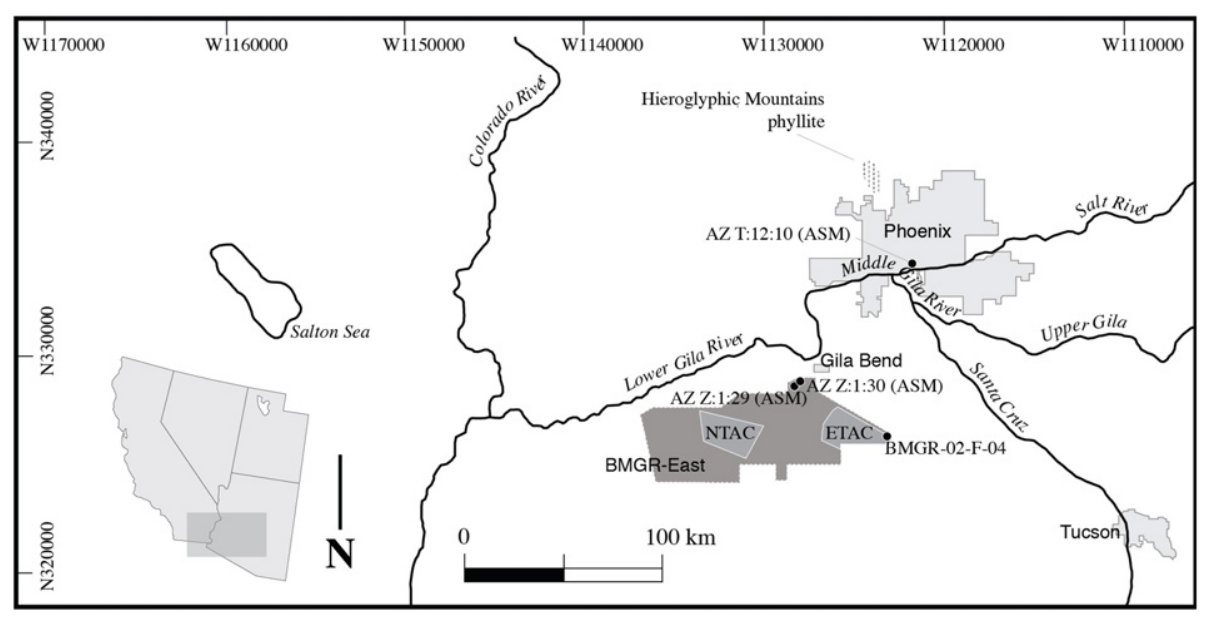

Fig. 1. Location of the study area within the southern U.S. Southwest. The Hieroglyphic Mountains phyllite source is mapped following Abbott and Watts (2010).

archaeologically in part by Lower Colorado Buff Ware ceramics, Lowland Patayan groups are best documented along the Colorado River and elsewhere in southwestern California (Hildebrand et al., 2002; Rogers, 1945; Schaefer, 1994; Waters, 1982a). Along the Colorado River, Lowland Patayan groups occupied pithouses or more ephemeral structures in seasonal settlements (Schaefer, 1994). Patayan habitation sites have been tentatively identified along the Lower Gila west of Gila Bend (Vivian, 1965), although none have been excavated (McGuire, 1982), and people probably moved seasonally away from riverine areas into the desert interior (Rogers, 1945; Schaefer, 1994). Their settlement patterns are less well understood in the areas closest to the Hohokam, as the Hohokam settlements dominated the riverine habitat around Gila Bend and to the east. Some Patayan apparently engaged in seasonal non-riverine agricultural activities as documented at the Mobak site (AZ Z:1:29 [ASM]), on an alluvial fan within $15 \mathrm{~km}$ of the Gila River (Hill and Bruder, 2000; Hill et al., 2008). More mobile foraging groups may have occupied other sites dominated by Patayan ceramics, such as Lago Seco (AZ Y:8:3 [ASM]), over $40 \mathrm{~km}$ south of the Gila River (Huckell, 1979).

The Gila Bend area was the eastern frontier of the Lowland Patayan before 1000 CE (Waters, 1982a). After 1000-1100 CE, the distribution of Lower Colorado Buff Ware expanded eastward (Waters, 1982a), along with the frequent use of materials from and adjacent to the Papaguería. These include the production of ornaments from Gulf of California shell (Howard, 1985;McGuire and Howard, 1987; Slaughter and Lascaux, 2000) and the use of Sauceda obsidian, collected from the Sauceda Mountains south of Gila Bend and nearby Sauceda Wash (Bayman, 1994; Doyel, 1996; Mitchell and Shackley, 1995; Shackley, 1988, 1995). Lower Colorado Buff Ware ceramics became more common in the eastern Papaguería (Goodyear, 1975; Masse, 1980; Severson, 1978; Yablon, 1978). They also appeared by 1000 CE or later in sites in the Lower Santa Cruz River Valley to the northeast (Deaver et al., 1990) and along the Lower Salt River (Beck, 2005). The easternmost appearance of Lowland Patayan ceramics occurred after $1150 \mathrm{CE}$ at the Hohokam site of Las Fosas (AZ U:15:19 [ASM]) along the Gila River (Crown, 1984:Table 2.7.2, 2.7.3). Sherd temper, which is common in Lower Colorado Buff Ware (Waters, 1982a, 1982b) and Hohokam ceramics from the Lower Gila area (Abbott, 2000a; Teague, 1981), appeared in plain ware from Lower Salt River Hohokam sites after 1150 CE (Mitchell et al., 1989:80). Aspects of the Patayan ceramic tradition eventually became part of the broader protohistoric ceramic tradition in the southern U.S. Southwest, including Patayan vessel forms and manufacturing techniques (Deaver et al., 1990).

The changing distribution of Patayan ceramics and ceramic traits probably reflects the movement of ancestral Yuman potters and other people as well as shifting exchange networks. Such a notion is supported by modern linguistic evidence for a prehistoric "multi-ethnic system" in the southern U.S. Southwest (Shaul and Hill, 1998:388) that included an "areal speech community" with many bilingual speakers of ancestral Piman and River Yuman languages some time before $1000 \mathrm{CE}$ (Shaul and Hill, 1998:380). Given the apparently peaceful co-existence and interaction of ancestral Yuman and Uto-Aztecan groups in the Gila Bend area after 700 CE (Beck and Neff, 2007) and continuing into the historical period (Ezell, 1963), it is plausible that some ancestral Yuman people joined existing Hohokam communities as they moved eastward into Uto-Aztecan territory after 1000 CE (Beck and Neff, 2007).

The best evidence for a resident Patayan group in a Hohokam site is between 1000-1200 CE at Las Colinas (AZ T:12:10 [ASM]) north of the Salt River. On the western end of two major Hohokam canal systems in the Lower Salt River valley, Las Colinas is located among the sites at the end of Canal System 2 on the west side of Cave Creek (Abbott, 2000b:Fig. 1.1, 25). An ancestral Yuman group may have occupied House Group XVII, where a relatively large Lower Colorado Buff Ware collection (4066 sherds and 12 reconstructible vessels) was recovered from contexts dating to approximately 1000-1200 CE (Beckwith et al., 1988). After $1150 \mathrm{CE}$, the proportion of obsidian coming from southern desert sources such as Sauceda increased enormously (Fertelmes et al., 2012). Las Colinas apparently continued to be a multi-ethnic community in the Classic period (Hill et al., 2004) with markers of Kayenta/ Tusayan identity such as perforated plates (Crown, 1981; Lyons, 2003) and local manufacture of Phoenix Red recurved-rim bowls (Abbott et al., 1988; Crown, 1981; Crown et al., 1988).

\subsection{Research questions}

In her original analysis of the Las Colinas ceramics, Beckwith (1988:216) suggested that the Lower Colorado Buff Ware vessels "originated somewhere along the Colorado River in the area between Yuma and Parker" or perhaps "in the vicinity of the Colorado River Indian Reservation," based on previously reported type distributions. These source areas are located at least 140 miles $(225 \mathrm{~km})$ from Las Colinas. In contrast, Beck and Neff (2007) argued that a resident Yuman population within Hohokam territory, at Las Colinas and elsewhere, would have made at least some of their Lower Colorado Buff Ware vessels locally from nearby riverine clays. The buff-firing Lower Gila River clays used for Lower Colorado Buff Ware in the Gila Bend area are similar to Middle Gila River clays in their timing and manner of deposition, color after firing, and chemical composition (Beck, 2006; Beck and Neff, 2007; Beck et al., 2012). Given that Hohokam potters substituted Lower Gila River clays for Middle Gila River clays to produce Hohokam Buff Ware (Abbott, 2000a; Lindauer, 1988; Teague, 1981), ancestral Yuman potters 
arguably could have used clays from the Salt-Gila Basin for Lower Colorado Buff Ware.

This study investigates the movement of ancestral Yuman people and objects through compositional analysis of Lower Colorado Buff Ware and associated wares to address the following questions: (1) Are the different regions sampled for this study compositionally distinct enough to reveal the movement of vessels? (2) Is Lower Colorado Buff Ware at Las Colinas compositionally similar to Hohokam Buff Ware at the site, suggesting manufacture in the Salt-Gila Basin? and (3) Is Lower Colorado Buff Ware at Las Colinas compositionally similar to sampled Lower Colorado Buff Ware from the Papaguería or southern California, suggesting manufacture in another region occupied by Lowland Patayan groups?

\section{Sample and methods}

Our study relies primarily on neutron activation analysis (NAA) conducted at the University of Missouri Research Reactor (MURR) and presents our previously unpublished analysis of 355 archaeological ceramic items from the Papaguería and from the Hohokam site of Las Colinas (AZ T:12:10 [ASM]; Table 1; see Fig. 1). The analyzed items are 353 sherds and two unfired archaeological clay pieces (one ceramic coil and one lump of clay). Our sample emphasizes types predating $1150 \mathrm{CE}$, although some later ceramics are present for comparison (Table 2), and deliberately incorporates sherds that were part of previous compositional studies as described further below. At the time of the analysis, all collections for this project were curated at Statistical Research, Inc. (SRI) or the Arizona State Museum (ASM), both in Tucson, Arizona.

The sample of 181 sherds from the Papaguería comes from the Barry M. Goldwater Range (BMGR)-East within three project areas (AUX-6, ETAC, and NTAC) and one rockshelter site, BMGR-02-F-04. The sites

Table 1

Sites included in this study by project area and number of NAA samples.

\begin{tabular}{|c|c|}
\hline Project area and site number & NAA samples \\
\hline \multicolumn{2}{|l|}{ BMGR-East: AUX-6 } \\
\hline AZ Z:1:29 & 84 \\
\hline$A Z Z: 1: 30$ & 5 \\
\hline \multicolumn{2}{|l|}{ BMGR-East: BMGR-02-F-04 } \\
\hline BMGR-02-F-04 & 62 \\
\hline \multicolumn{2}{|l|}{ BMGR East: ETAC } \\
\hline AZ Z:2:63 & 1 \\
\hline$A Z Z: 2: 65$ & 1 \\
\hline AZ Z:6:100 & 1 \\
\hline AZ Z:6:103 & 1 \\
\hline AZ Z:6:112 & 2 \\
\hline AZZ:6:115 & 1 \\
\hline AZZ:6:118 & 2 \\
\hline AZ Z:6:167 & 1 \\
\hline AZ Z:6:176 & 1 \\
\hline AZ Z:6:183 & 1 \\
\hline \multicolumn{2}{|l|}{ BMGR East:ETAC } \\
\hline AZ Y:8:17 & 1 \\
\hline AZ Y:8:19 & 1 \\
\hline AZ Y:8:23 & 1 \\
\hline AZ Y:8:44 & 1 \\
\hline AZ Y:8:80 & 2 \\
\hline AZ Y:8:84 & 1 \\
\hline AZ Y:8:85 & 1 \\
\hline AZ Y:8:99 & 2 \\
\hline AZ Y:8:102 & 1 \\
\hline AZ Y:8:104 & 1 \\
\hline AZ Y:8:105 & 2 \\
\hline AZ Y:8:106 & 1 \\
\hline AZ Y:8:110 & 1 \\
\hline AZ Y:8:200 & 1 \\
\hline AZ Y:8:203 & 1 \\
\hline \multicolumn{2}{|l|}{ Phoenix Basin } \\
\hline AZ T:12:10 (ASM) & 174 \\
\hline TOTAL & 335 \\
\hline
\end{tabular}

Table 2

Group membership of NAA samples by ceramic ware and recovery location.

\begin{tabular}{|c|c|c|c|c|c|c|c|c|c|}
\hline Ware and location & 1 & 2 & 3 & 4 & 5 & 6 & 7 & Unassigned & Total \\
\hline \multicolumn{10}{|l|}{ Lower Colorado Buff Ware } \\
\hline BMGR-East: AUX-6 & & 8 & 36 & & & & & 13 & 57 \\
\hline BMGR-East: BMGR-02-F-04 & & & 6 & & & 1 & & 4 & 11 \\
\hline BMGR-East: ETAC & & & 6 & & & & & 3 & 9 \\
\hline BMGR-East: NTAC & & & 6 & & & & & 4 & 10 \\
\hline Las Colinas & 86 & 2 & 1 & & & & & 24 & 113 \\
\hline \multicolumn{10}{|l|}{ Hohokam Buff Ware } \\
\hline BMGR-East: AUX-6 & & 4 & & & & & & 1 & 5 \\
\hline BMGR-East: BMGR-02-F-04 & & 7 & & 1 & & & & 1 & 9 \\
\hline Las Colinas & 2 & 36 & 6 & 11 & & & & 4 & 59 \\
\hline \multicolumn{10}{|l|}{ Historical-period Piman or } \\
\hline BMGR-East: BMGR-02-F-04 & & 2 & & & & & & 3 & 5 \\
\hline BMGR-East: ETAC & & & & & & 1 & & & 1 \\
\hline \multicolumn{10}{|l|}{ Indeterminate buff ware } \\
\hline BMGR-East: ETAC & & & & & & & & 1 & 1 \\
\hline BMGR-East: NTAC & & & 1 & & & & & & 1 \\
\hline \multicolumn{10}{|l|}{ Unfired clay objects } \\
\hline Las Colinas & & & 1 & & & & & 1 & 2 \\
\hline \multicolumn{10}{|l|}{ Papagueria brown painted ware } \\
\hline BMGR-East: BMGR-02-F-04 & & 2 & 1 & 3 & & & & 2 & 8 \\
\hline \multicolumn{10}{|l|}{ Brown plain ware } \\
\hline BMGR-East: AUX-6 & & & 12 & 1 & & 2 & & 12 & 27 \\
\hline BMGR-East: BMGR-02-F-04 & & & & & 12 & 3 & & 4 & 19 \\
\hline BMGR-East: ETAC & & & & & & 1 & & & 1 \\
\hline BMGR-East: NTAC & 1 & & & & & 1 & & 4 & 6 \\
\hline \multicolumn{10}{|l|}{ Red ware } \\
\hline BMGR-East: NTAC & & & 1 & & & & & & 1 \\
\hline \multicolumn{10}{|l|}{$\begin{array}{l}\text { Tucson Basin brown painted } \\
\text { ware }\end{array}$} \\
\hline BMGR-East: BMGR-02-F-04 & & & & & & & 8 & 2 & 10 \\
\hline TOTAL & 89 & 61 & 77 & 16 & 12 & 9 & 8 & 83 & 355 \\
\hline
\end{tabular}

sampled include Mobak (84 sherds; AZ Z:1:29 [ASM]) and Rainy Day ( 5 sherds; AZ Z:1:30 [ASM]) from the AUX-6 project by Dames and Moore (Hill and Bruder, 2000; Hill et al., 2008), ten sites on ETAC (12 sherds; Lyon, 2000) and 15 sites on NTAC (18 sherds; Thurtle, 2001; Tucker, 2000) surveyed by SWCA, Inc., and Rockshelter 4 (62 sherds; BMGR-02-F-04), investigated by Statistical Research, Inc. (Doolittle, 2004). The sample focused on Lower Colorado Buff Ware and Hohokam Buff Ware, but included some historical-period Piman or Maricopa buff ware, indeterminate buff ware, indeterminate red ware, Papagueria brown painted ware, Tucson Basin brown painted ware (Tanque Verde Red-on-brown), and plain ware for comparison.

A portion of the Papaguería sample-141 sherds from Mobak (AZ Z:1:29 [ASM]), Rainy Day (AZ Z:1:30 [ASM]), and Rockshelter 4 (BMGR-02-F-04)-was previously analyzed by laser-ablation inductively-coupled plasma mass spectrometry (LA-ICP-MS;Beck and Neff, 2007). These 141 sherds make up 94\% of the 150 samples analyzed by (Beck and Neff, 2007) and were chosen because sufficient material remained for NAA after the original LA-ICP-MS study. All 89 sherds from the Mobak and Rainy Day sites were also analyzed in an earlier petrographic study (Miksa, 2000), permitting comparison of the petrographic, LA-ICP-MS, and NAA results for this subset. All 30 sherds from the ETAC and NTAC sites were part of a larger study describing regional geology and temper types across the western Papaguería (Gregonis et al., 2001).

The sample from Las Colinas includes 113 Lower Colorado Buff Ware sherds, 59 Hohokam Buff Ware sherds, and two unfired archaeological samples of clay (recovered as lumps or coils). Five of the Lower Colorado Buff Ware sherds with phyllite temper were also submitted for petrographic analysis and chemical analysis by SED-EDS for comparison with known phyllite sources in central Arizona (Abbott et al., 2012).

Comparative NAA data are drawn from 38 natural clay samples collected along the Lower and Middle Gila River in Arizona (Beck et al., 2012) and from Hildebrand et al. (2002), whose project in southern California includes 75 sherds and 25 natural clay samples collected in the 
area around the Salton Sea west to the coast. Relevant samples here include 12 Lower Colorado Buff Ware sherds (Tumco and Topoc Buff) and four natural clay samples from Salton Trough sediments (Holocene Lake Cahuilla and the Palm Springs Formation), all of which cluster into Hildebrand et al.'s chemical group IMP-1A. The natural clay samples analyzed by Beck et al. (2012) were not included when defining the compositional clusters described below, although the Lower Gila samples had been included in clusters in a previous report of our study (Beck et al., 2009; Schwarz et al., 2009).

Statistical methods for defining clusters were similar to those previously used for chemical data collected by NAA (Glascock, 1992; Neff, 2002). In brief, a variety of pattern-recognition techniques were used to identify possible reference groups in the data, and these protogroups were then refined by statistical group evaluation using Mahalanobis distances.

\section{Results}

We defined seven NAA compositional groups (Fig. 2; see Table 2) that include 272 of the analyzed sherds and one of the unfired pieces from Las Colinas (of the 355 specimens analyzed, 83-or 23\%-were unassigned). Group 1 consists almost entirely of Lower Colorado Buff Ware recovered from Las Colinas. Group 2 is dominated by Hohokam Buff Ware from all sites, with a few pieces of Lower Colorado Buff Ware and historical-period Piman or Maricopa ceramics. Group 3 primarily contains Lower Colorado Buff Ware from the BMGR, with some brown plain ware from the BMGR and a few pieces of Hohokam Buff Ware from Las Colinas. It also includes the unfired ceramic coil from Las Colinas. Group 4 consists primarily of Hohokam Buff Ware from Las Colinas. Brown plain ware from the BMGR makes up all of Group 5 and most of Group 6. All of the Tucson Basin brown painted ware (Tanque Verde Red-on-brown) falls into Group 7.

None of the specimens (either in Groups 1-7 or unassigned) plot within a previously defined Lower Colorado Buff Ware group from southeastern California (Hildebrand et al., 2002). No specimen has more than $1.7 \%$ probability of membership in the Desert Buff compositional group, with most of the samples having less than $0.005 \%$ probability of membership.

As noted earlier, $23 \%$ of the specimens overall were unassigned, and these were drawn from all ceramic wares and project areas. Combinations especially prone to being unassigned (and that have five or more specimens) are Lower Colorado Buff Ware from NTAC (40\%), brown plain ware from NTAC (67\%), brown plain ware from AUX-6 (44\%), and historical-period Piman or Maricopa ceramics from BMGR-02-F04, which is almost the entire sample of historical-period Piman or Maricopa ceramics in the study (60\%).

For 141 sherds from the Papaguería, group membership can be compared between LA-ICP-MS analysis (Beck and Neff, 2007) and NAA as reported here (Table 3 ). Cluster A in the LA-ICP-MS study included most Hohokam Buff Ware and almost half of the Lower Colorado Buff Ware. Nine of the ten Cluster A sherds that could be assigned to a source area petrographically were local to the Mobak/Rainy Day area (Miksa, 2000). Cluster B was dominated by Lower Colorado Buff Ware, and all nine of the Cluster B sherds that could be assigned to a source area petrographically were local to the Mobak/Rainy Day area (Miksa, 2000). Based on the petrographic data, use of Lower Gila River clays was assumed for both Cluster A and B (Beck and Neff, 2007). Cluster A split between NAA Groups 2 and 3 along ware lines, while Cluster B went primarily into NAA Group 3.

\section{Discussion}

In this NAA study, there are groups dominated by buff ware (Groups 1-3) and groups dominated by brown ware (Groups 4-7). We can discern some geographic patterning in our results. Tucson Basin brown painted ware is compositionally distinct from brown ware, either plain or painted, from the Papaguería. Lower Colorado Buff Ware from Las Colinas almost always splits away from Lower Colorado Buff Ware from the BMGR. Finally, none of the analyzed specimens have a southeastern California provenance, based on comparative data (Hildebrand et al., 2002). Our results are more illuminating when combined with other lines of evidence, such as petrographic, LA-ICP-MS, and scanning

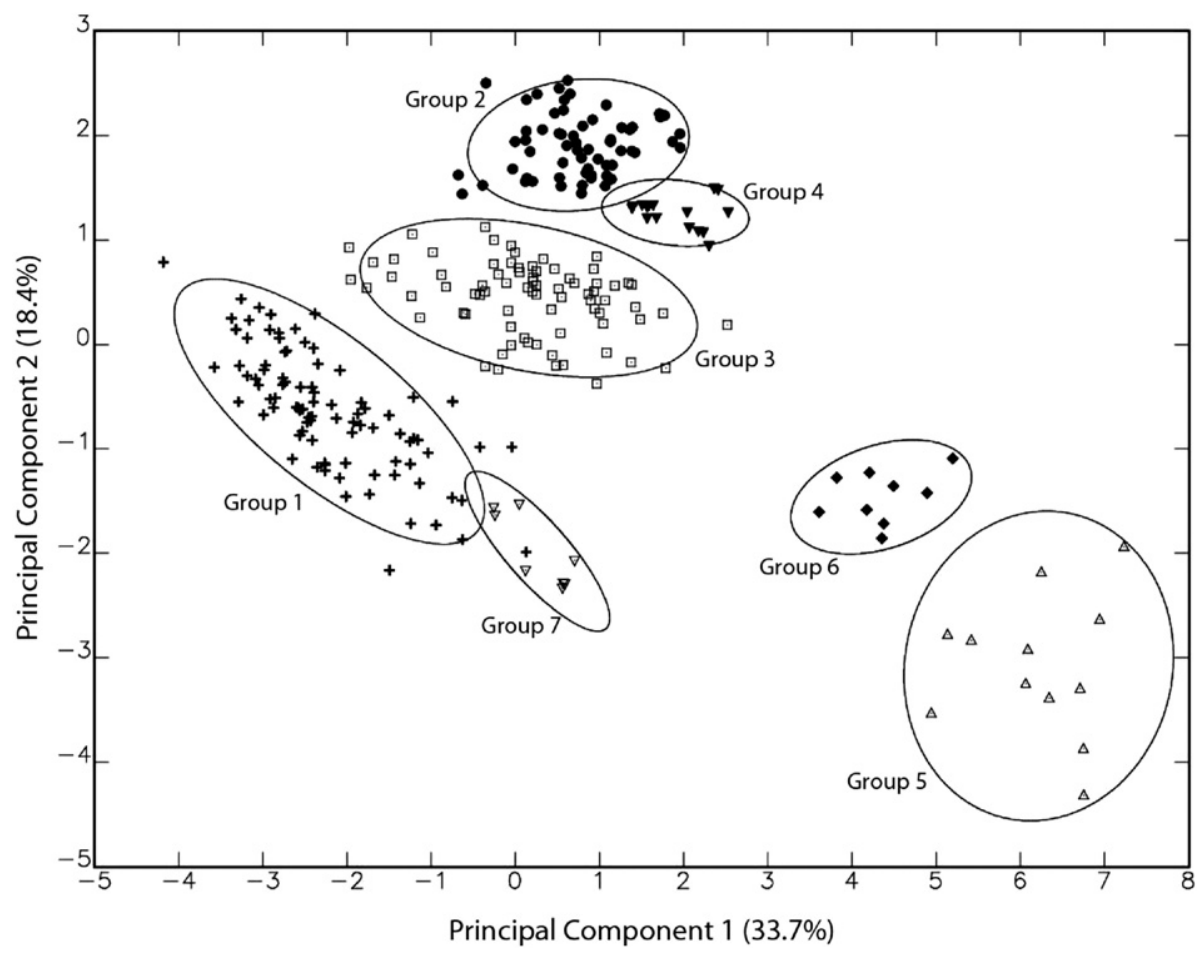

Fig. 2. The seven compositional groups defined using NAA plotted against Principal Components 1 and 2. 
Table 3

Group membership of NAA samples (Groups 1-7) by group membership (Clusters A-E) in LA-ICP-MS analysis (Beck and Neff, 2007).

\begin{tabular}{|c|c|c|c|c|c|c|c|}
\hline INAA group & A & B & C & $\mathrm{D}$ & E & Unassigned & Total \\
\hline 1 & & & & & & & 0 \\
\hline 2 & 12 & 3 & & & & 5 & 20 \\
\hline 3 & 16 & 24 & 1 & 1 & 2 & 8 & 52 \\
\hline 4 & & 1 & & 2 & & 1 & 4 \\
\hline 5 & & & 8 & & 4 & & 12 \\
\hline 6 & & 1 & 4 & & & 1 & 6 \\
\hline 7 & & & & & 8 & & 8 \\
\hline Unassigned & 13 & 7 & 6 & 1 & 1 & 11 & 39 \\
\hline Total & 41 & 36 & 19 & 4 & 15 & 26 & 141 \\
\hline
\end{tabular}

electron microscopy with energy-dispersive X-ray spectroscopy (SEMEDS) data.

The previous LA-ICP-MS analysis (Beck and Neff, 2007) grouped some Hohokam Buff Ware and Lower Colorado Buff Ware together in Cluster A. LA-ICP-MS identifies the chemical composition of targeted areas of the paste, and was chosen by (Beck and Neff, 2007) to exclude mineral inclusions larger than silt size. Similar buff-firing clays, appearing as floodplain deposits from the Gila River when it was a meandering river system approximately $800-1500$ years ago, are available along both the Lower and Middle Gila River (Beck and Neff, 2007; Beck et al., 2012). Beck and Neff (2007:297) explained LA-ICP-MS Cluster A as use of Lower Gila River clays to "make some locally-produced Hohokam Buff Ware and Lower Colorado Buff Ware dating to the period AD 700-1150. Lower Colorado Buff Ware could be, and in the Gila Bend area was, produced with the same raw materials available to Hohokam potters." Earlier studies (Abbott, 2000a; Lindauer, 1988; Teague, 1981) concur that some Hohokam Buff Ware was produced in the Gila Bend area.

Although some Hohokam Buff Ware and Lower Colorado Buff Ware specimens are compositionally similar when only finer particle sizes are analyzed, grouping together in Cluster A (Beck and Neff, 2007), these wares split apart into two NAA compositional groups (Groups 2 and 3; see Table 3). Shared methods of paste preparation, including the use of temper, are important for compositional groups because the bulk chemical composition analyzed by NAA reflects both the raw "clay" (which includes clay, silt, and sand fractions) and also additions or deletions by the potters (Arnold et al., 1991; Neff, 1993). Almost all Hohokam Buff Ware sherds from both Las Colinas and the BMGR cluster together in NAA Group 2, even though these ceramics probably include vessels manufactured along the Middle Gila (recovered from Las Colinas) and the Lower Gila (recovered from the BMGR). In spite of previous optimism that Lower Gila River and Middle Gila River clays could be chemically distinguished (Beck et al., 2012), temper seems to overwhelm any such distinction. The mica schist temper causes most samples of this ware to group together, obscuring differences in production area. Abbott (2011, 2000a, 2000b) has also observed this effect of mica schist and therefore tried to exclude temper from Hohokam Buff Ware chemical analyses by using electron microprobe and laser ablation.

Of the two unfired archaeological clay pieces from Las Colinas, the ceramic coil fell into Group 3 and the clay lump was unassigned. Group 3 is primarily Lower Colorado Buff Ware from the BMGR. One Lower Gila River clay sample described in Beck et al. (2012; sample MEB364 from Trench 19, SS7) also clustered with the Group 3 ceramics in an earlier version of this study (Beck et al., 2009; Schwarz et al., 2009). We are not suggesting that NAA Group 3 represents a single production area for all of these pieces, given that much of the Lower Colorado Buff Ware appears to be made in the Papaguería (based on petrographic data) and the ceramic coil is assumed to be local to Las Colinas. Group 3 may instead represent a cluster of chemically similar clays with limited aplastics and much less, if any, mica schist. The ceramic coil does not appear to be tempered and contains only sparse sand particles. Our attempts to find subgroups within Group 3 were unsuccessful, despite documented mineralogical variation. Identified plastics in the Lower Colorado Buff Ware and brown plain ware specimens in Group 3 include grog, quartz sand, granitic particles, schist, basalt, unidentified volcanic grains, and occasionally obsidian (Gregonis et al., 2001; Miksa, 2000).

Of the 63 Lower Colorado Buff Ware specimens from the BMGR that could be assigned to a group, 54 (86\%) belong to Group 3. One stray appears in Group 6 with brown plain ware from the BMGR, but the vast majority of the remainder ( 8 specimens from AUX-6) fall into Group 2 with Hohokam Buff Ware. Based on Miksa's (2000) petrography study, three of the eight contain gneiss/schist-which probably explains their presence in Group 2-but the other five are sand-tempered with quartz and unidentified rock fragments.

The relationship of the Lower Colorado Buff Ware at Las Colinas to other samples is most important for this study. Of the 89 Las Colinas Lower Colorado Buff Ware sherds that could be assigned to a group, 86 of them cluster in Group 1 separate from almost all of the other ceramics. These were apparently not made in two known production areas for Lower Colorado Buff Ware-the Papaguería of southwestern Arizona or in southeastern California-given that they are compositionally distinct from Lower Colorado Buff Ware sherds from the BMGR (Group 3) and do not have reasonable probabilities of membership in a previously defined Lower Colorado Buff Ware group from southeastern California (Hildebrand et al., 2002).

This result prompted Beck et al. (2009) to suggest local production of Lower Colorado Buff Ware at Las Colinas. Later petrographic and chemical (SEM-EDS) analyses of five phyllite-tempered sherds (two from Group 1 and three previously unanalyzed sherds from the Las Colinas collection), however, revealed that the phyllite temper did not come from the Phoenix Mountains near the site (Abbott et al., 2012). The phyllite could not be clearly linked to any other known source, leading Abbott et al. (2012:991) to conclude that "despite our confidence that the Patayan ceramics at Las Colinas were not made there, we still do not know where they originated." Subsequent attempts to find subgroups within Group 1, as with Group 3, were unsuccessful. It is a remarkably tight cluster, despite some variation in temper. Although 48 (56\%) of the Group 1 sherds contain phyllite and another 10 (12\%) contain mica schist, other sherds in this group lack these materials (as observed by hand lens) and instead contain basalt, quartz, or grog.

\section{Conclusions}

Lowland Patayan ceramic technology moved eastward after $1000 \mathrm{CE}$, but apparently not through the long-distance movement of vessels. We find no evidence of direct vessel exchange or transport between different regions occupied by the Lowland Patayan (southern California, the eastern Papaguería, and Las Colinas near the Salt River). Although long-distance movement of Lower Colorado Buff Ware seems unlikely, vessels may have been moved over shorter distances. We still do not know where the Patayan ceramics at Las Colinas were made, since they appear to be neither locally manufactured nor brought from the Papaguería or farther west. The currently documented phyllite sources (Abbott and Watts, 2010: Fig. 2; Abbott et al., 2008) are in the uplands to the north of Las Colinas. Investigations to the west of this area, including the western flank of the Hieroglyphic Mountains (see Fig. 1), might reveal additional Patayan communities within a severaldays walk of Las Colinas and the source of phyllite used in the Las Colinas Lower Colorado Buff Ware (David Abbott, personal communication, May 2010).

Identifying vessel movement within the eastern Papaguería would have been especially interesting, in light of larger questions about the size and changing location of Lowland Patayan regional territories here. Unfortunately, we could not discern these patterns in our study. The vast majority of Lower Colorado Buff Ware from all project areas of the BMGR lumps together in Group 3, in spite of the documented 
mineralogical variation (Gregonis et al., 2001; Miksa, 2000), when we had hoped instead for some separation between the AUX-6, ETAC/ BMGR-02-F-04, and NTAC areas. A similar lumping also happens when using bulk chemical composition in Hohokam Buff Ware, prompting researchers to analyze clay and aplastic inclusions separately (Abbott, 2009, 2011, 2000a, 2000b; Abbott et al., 2007). Petrographic analysis is probably the most promising analytical technique for identifying areas of manufacture in this region, once the geographic availability of some of the less common inclusions (such as obsidian and other volcanics) is better understood.

\section{Acknowledgments}

Sincere thanks go to the many people who have been generous with their time, collections, and feedback, including David Doyel and Adrienne Rankin (Luke Air Force Base), Arthur Vokes (Arizona State Museum), Jill Onken (University of Arizona), Jody Holmes (Statistical Research, Inc.), Jerome Hesse (SWCA), David R. Abbott (Arizona State University), and Danielle K. Schwarz and Michael D. Glascock (MURR). We also appreciate assistance from Chris Hunt, co-editor of Journal of Archaeological Science: Reports, and from two anonymous reviewers whose comments substantially improved the paper. The compositional analysis was funded under National Science Foundation awards to Margaret Beck (BCS-0830269) and to MURR (BCS-0802757).

\section{Appendix A. Supplementary data}

Supplementary data to this article can be found online at http://dx. doi.org/10.1016/j.jasrep.2016.05.008.

\section{References}

Abbott, D.R., 2000a. Hohokam Buff Ware production and distribution and the provenance of decorated pottery from the BMGR. In: Lyon, J.D. (Ed.), Procurement, Processing, and Passing Through, Volume II: An Archaeological Survey of 14,390 Acres in the Central Sauceda Valley (East TAC) on the Barry M. Goldwater Range in Southwestern Arizona. SWCA Environmental Consultants, Tucson, Arizona, pp. 577-619 SWCA Cultural Resource Report No. 98-267.

Abbott, D.R., 2000b. Ceramics and Community Organization Among the Hohokam. The University of Arizona Press, Tucson.

Abbott, D.R., 2009. Extensive and long-term specialization: Hohokam ceramic production in the Phoenix Basin, Arizona. Am. Antiq. 74, 531-557.

Abbott, D.R., 2011. Chemical analyses of the clay fractions in the crimson ruin buff ware pottery. In: Henderson, T.K. (Ed.), Crismon Ruin: A Hohokam Settlement at the Head of the Lehi Canal System. Center for Desert Archaeology, Tucson, pp. 243-248 Anthropological Papers No. 44

Abbott, David R., and David A. Gregory 1988 Hohokam ceramic wares and types. In The 1982-1984 Excavations at Las Colinas: Material Culture, by David R. Abbott, Kim E. Beckwith, Patricia L. Crown, R. Thomas Euler, David A. Gregory, J. Ronald London, Marilyn B. Saul, Larry A. Schwalbe, and Mary Bernard-Shaw, pp. 5-28. Archaeological Series 162, Volume 4. Arizona State Museum, Tucson.

Abbott, D.R., Kelly, S.E., Lack, A., Beck, M., 2012. Testing the provenance of Patayan pottery at Las Colinas: chemical and petrographic analyses of phyllite-temper fragments. J. Archaeol. Sci. 39, 984-993.

Abbott, D.R., Lack, A.D., Hackbarth, M.R., 2008. Provenance and microprobe assays of phyllite-tempered ceramics from the uplands of Central Arizona. Geoarchaeology: An International Journal 23, 213-242.

Abbott, D.R., Watts, J., 2010. Identical rock types with different chemistry: sourcing phyllite-tempered Hohokam pottery from the Phoenix Basin, Arizona. J. Archaeol. Sci. 37, 1612-1622.

Abbott, D.R., Watts, J., Lack, A., 2007. The provenance and concentrated production of Hohokam red-on-buff pottery: implications for an ancient Arizona economy. J. Anthropol. Res. 63, 331-357.

Arnold, D.E., Neff, H., Bishop, R.L., 1991. Compositional analysis and "sources" of pottery: an ethnoarchaeological approach. Am. Anthropol. 93, 70-90.

Bayman, J.M., 1994. Craft Production and Political Economy at the Marana Platform Mound Community Unpublished Ph.D. dissertation Department of Anthropology, Arizona State University, Tempe.

Beck, M.E., 2005. Ceramic Analysis. Archaeological Testing at AZ T:11:94(ASM), Tres Rios Project, Maricopa County, Arizona, by Jill Onken and Richard Ciolek-Torrello, pp. 65-68. Technical Report Statistical Research, Inc, Redlands, California, pp. 04-39.

Beck, M.E., 2006. Linking finished ceramics to raw materials: oxidized color groups for lowland desert clays. Kiva: The Journal of Southwestern Anthropology and History 72 (1), 93-118

Beck, M.E., Neff, H., 2007. Hohokam and Patayan interaction in southwestern Arizona: evidence from ceramic compositional analyses. J. Archaeol. Sci. 34 (2), 289-300.
Beck, M.E., Jill, O., Sunday Eiselt, B., Andrew Darling, J., Ferguson, J., 2012. Geomorphological setting of buff-firing pottery clays in the lower Gila Valley, southwestern Arizona. J. Archaeol. Sci. 39, 321-331.

Beck, M.E., Schwarz, D.K., Glascock, M.D., 2009. Interaction and Migration in the Sonoran Desert: A View from Ceramic Compositional Analysis. Poster Presented at the 74th Annual Meeting of the Society for American Archaeology, Atlanta, Georgia.

Beckwith, Kim E. 1988 Intrusive wares and types. In The 1982-1984 Excavations at Las Colinas: Material Culture, by David R. Abbott, Kim E. Beckwith, Patricia L. Crown, R. Thomas Euler, David A. Gregory, J. Ronald London, Marilyn B. Saul, Larry A. Schwalbe, and Mary Bernard-Shaw, pp. 199-256. Archaeological Series 162, Volume 4. Arizona State Museum, Tucson.

Crown, P.L., 1981. Analysis of the Las Colinas ceramics. In: Hammack, L.C., Sullivan, A.P. (Eds.), The 1968 Excavations at Mound 8, Las Colinas Ruins Group, Phoenix, Arizona. Arizona State Museum, Tucson, pp. 87-169 Archaeological Series No. 154.

Crown, P.L. 1984. Ceramic vessel exchange in southern Arizona. In: Teague, L. Crown, P. (Eds.), Hohokam Archaeology along the Salt-Gila Aqueduct, Central Arizona Project, Volume 9: Synthesis and Conclusions. Arizona State Museum, Tucson, pp. 251-304 Archaeological Series No. 150.

Crown, Patricia L., Larry A. Schwalbe, and J. Ronald London 1988 X-ray fluorescence analysis of materials variability in Las Colinas ceramics. In The 1982-1984 Excavations at Las Colinas: Material Culture, by David R. Abbott, Kim E. Beckwith, Patricia L. Crown, R. Thomas Euler, David A. Gregory, J. Ronald London, Marilyn B. Saul, Larry A. Schwalbe, and Mary Bernard-Shaw, pp. 29-71. Archaeoleogical Series 162, Volume 4. Arizona State Museum, Tucson.

Deaver, William 1990 Native American ceramics. In Archaeology of the Ak-Chin Indian Community West Side Farms Project: Material Cultural and Human Remains, compiled by Robert E. Gasser, Christine K. Robinson, and Cory Dale Breternitz, pp. 15.1-15.21. Soil Systems Publications in Archaeology No. 9, Volume 4. Phoenix.

Doolittle, C.J., 2004. Damage Assessment of Four Rockshelters on the Barry M. Goldwater Range (administrative draft). Technical Report 04-18. Statistical Research, Inc., Tucson, Arizona.

Doyel, D.E., 1996. Resource mobilization and Hohokam society: analysis of obsidian artifacts from the Gatlin site, Arizona. Kiva 62, 45-60.

Doyel, D.E., 2000. Settlement organization at Gila Bend. In: Doyel, D.E., Fish, S.K., Fish, P.R. (Eds.), The Hohokam Village Revisited. Southwestern and Rocky Mountain Division of the American Association for the Advancement of Science, Fort Collins, Colorado, pp. 101-138.

Ezell, Paul 1963 The Maricopas: An Identification from Documentary Sources. University of Arizona Anthropological Papers Number 6. The University of Arizona Press, Tucson, 1963.

Fertelmes, C.M., Abbott, D.R., Steven Shackley, M., 2012. Obsidian source characterization at Las Colinas: shifting exchange patterns during the Hohokam sedentary-classic transition. Kiva 77, 281-312.

Glascock, M.D., 1992. Characterization of archaeological ceramics at MURR by neutron activation analysis and multivariate statistics. In: Neff, H. (Ed.), Chemical Characterization of Ceramic Pastes in Archaeology. Prehistory Press, Madison, Wisconsin, pp. 11-26 Monographs in World Archaeology No. 7.

Goodyear III, A.C., 1975. Hecla II and III: An Interpretive Study of Archaeological Remains from the Lakeshore Project, Papago Reservation, South Central Arizona Anthropological Research Paper No. 9 Arizona State University, Tempe.

Gregonis, L.M., Carpenter, A.J., Mauz, K., Lyon, J.D., 2001. A preliminary analysis of ceramic tempers on the BMGR. In: Thurtle, M.C. (Ed.), The Cultural Landscape of Okie Hill: An Archaeological Survey of 5,355 Acres on the North Tactical Range of the Barry M. Goldwater Range in Southwestern Arizona. SWCA Environmental Consultants, Tucson, pp. 241-313 SWCA Cultural Resource Report No. 99-205.

Hildebrand, J.A., Gross, G.T., Schaefer, J., Neff, H., 2002. Patayan ceramic variability: using trace elements and petrographic analysis to study brown and buff wares in southern California. In: Glowacki, D.M., Neff, H. (Eds.), Ceramic Production and Circulation in the Greater Southwest: Source Determination by NAA and Complementary Mineralogical Investigations. The Cotsen Institute of Archaeology, University of California, Los Angeles, pp. 121-139 Monograph 44.

Hill, J.B., Clark, J.J., Doelle, W.H., Lyons, P.D., 2004. Prehistoric demography in the southwest: migration, coalescence, and Hohokam population decline. Am. Antiq. 69 (4), 689-716.

Hill Jr., M.E., Simon Bruder, J. (Eds.), 2000. Farmers and Foragers or Cultivators and Collectors?: Opportunistic Occupation in the Interior Desert of the Western PapagueriaDames and Moore Intermountain Cultural Resource Services Research Paper No Vol. 57. Dames and Moore, Phoenix, Arizona.

Hill Jr., M.E., Simon Bruder, J., Beck, M.E., Phillips, B.G., 2008. Mobile horticulturalists in the Western Papagueria. Kiva: The Journal of Southwestern Anthropology and History 74 (1), 33-69.

Howard, A.V., 1985. A reconstruction of Hohokam interregional shell production and exchange within southwestern Arizona. In: Dittert Jr., A.E., Dove, D.E. (Eds.), Proceedings of the 1983 Hohokam Symposium, pp. 459-472 Phoenix Chapter, Arizona Archaeological Society, Occasional Paper No. 2. Phoenix.

Huckell, B.B., 1979. The Coronet Real Project: Archaeological Investigations on the Luke Range, Southwestern Arizona Arizona State Museum Archaeological Series No. 129. Tucson, Arizona.

Lindauer, O., 1988. A Study of Vessel Form and Painted Designs to Explore Regional Interaction of the Sedentary Period Hohokam Ph.D. dissertation Arizona State University, Tempe.

Lyon, J.D. (Ed.), 2000. Procurement, Processing, and Passing Through, Volume II: An Archaeological Survey of 14,390 Acres in the Central Sauceda Valley (East TAC) on the Barry M. Goldwater Range in Southwestern Arizona. SWCA Environmental Consultants, Tucson, Arizona SWCA Cultural Resource Report No. 98-267. 
Lyons, P.D., 2003. Ancestral Hopi Migrations. Anthropological Papers No. 68. The University of Arizona Press, Tucson.

Masse, W.B., 1980. Excavations at Gu Achi: A Reappraisal of Hohokam Settlement and Subsistence in the Arizona Papagueria Western Archaeological Center Publications in Anthropology No. 12. Tucson.

McGuire, R.H., 1982. Problems in culture history. In: McGuire, R.H., Schiffer, M.B. (Eds.), Hohokam and Patayan: Prehistory of Southwestern Arizona. Academic Press, New York, pp. 153-222.

McGuire, R.H., Howard, A.V., 1987. The structure and organization of Hohokam shell exchange. The Kiva 52, 113-146.

Miksa, Elizabeth 2000 Ceramic petrographic analysis. In Farmers and Foragers or Cultivators and Collectors?: Opportunistic Occupation in the Interior Desert of the Western Papagueria, prepared by Matthew E. Hill, Jr., and J. Simon Bruder, pp. E-1-E-13. Dames and Moore Intermountain Cultural Resource Services Research Paper No. 57. Dames and Moore, Phoenix.

Mills, B.J., Clark, J.J., Peeples, M., Haas Jr., W.R., Roberts Jr., J.M., Hill, B., Huntley, D.L., Borck, L., Breiger, R.L., Clauset, A., Shackley, M.S., 2013. The transformation of social networks in the Late Prehispanic U.S. Southwest. Proc. Natl. Acad. Sci. 110 (15), 5785-5790.

Mills, B.J., Peeples, M.A., Haas Jr., W.R., Borck, L., Clark, J.J., Roberts Jr., J.M., 2015. Multiscalar perspectives on social networks in the Late Prehispanic Southwest. Am. Antiq. 80, 3-24.

Mitchell, D.R., Lane, A.M., Mitchell, D.R., 1989. The El Caserío Ceramic Assemblage. El Caserío: Colonial Period Settlement Along the East Papago Freeway. Soil Systems, Inc., Phoenix, Arizona, pp. 77-101 Soil Systems Publications in Archaeology No. 14.

Mitchell, D.R., Shackley, M.S., 1995. Classic period Hohokam obsidian studies in southern Arizona. Journal of Field Archaeology 22 (3), 291-304.

Neff, H., 1993. Theory, sampling, and analytical techniques in the archaeological study of prehistoric ceramics. Am. Antiq. 58, 23-44.

Neff, H., 2002. Quantitative techniques for analyzing ceramic compositional data. In: Glowacki, D.M., Neff, H. (Eds.), Ceramic Production and Circulation in the Greater Southwest: Source Determination by NAA and Complementary Mineralogical Investigations. The Cotsen Institute of Archaeology, University of California, Los Angeles, pp. 15-36 Monograph 44.

Rogers, M.J., 1945. An outline of Yuman prehistory. Southwest. J. Anthropol. 1 (2), 167-198.

Schaefer, J., 1994. The stuff of creation: recent approaches to ceramics analysis in the Colorado desert. In: Ezzo, J.A. (Ed.), Recent Research Along the Lower Colorado River, pp. 81-100 Technical Series No. 51, Statistical Research, Tucson.

Schwarz, D.K.H., Beck, M.E., Glascock, M.D., 2009. Neutron Activation Analysis of Hohokam and Patayan Pottery from Southwestern Arizona (MEB001-350: Pottery; MEB351-370: Clays) Report on file at the Research Reactor Center University of Missouri.
Severson, Marc B. 1978 Ceramics. In The Quijotoa Valley Project, by E. Jane Rosenthal, Douglas R. Brown, Marc Severson, and John B. Clonts, pp. 84-134. Cultural Resources Management Division, Western Archaeological Center, National Park Service, Tucson, Arizona.

Shackley, M.S., 1988. Sources of archaeological obsidian in the southwest: an archaeological, petrological, and geochemical study. Am. Antiq. 53, 752-772.

Shackley, M.S., 1995. Sources of archaeological obsidian in the greater American southwest: an update and quantitative analysis. Am. Antiq. 60, 531-551.

Shaul, D.L., Andresen, J.M., 1989. A case for Yuman participation in the Hohokam regional system. Kiva 54, 105-126.

Shaul, D.L., Hill, J.H., 1998. Tepimans, Yumans, and Other Hohokam. Am. Antiq. 63. 375-396.

Slaughter, M.C., Lascaux, A., 2000. Trade corridors and ethnic boundaries. In: Slaughter M.C., Tucker, D.B., Lascaux, A. (Eds.), Trade Corridors and Ethnic Boundaries: An Archaeological Survey of 12,089 Acres along the Growler and San Cristobal Washes on the Barry M. Goldwater Range in Southwestern Arizona. ARCADIS Geraghty and Miller, Environmental Services, Phoenix and SWCA, Environmental Consultants, Tucson, pp. 511-526 SWCA Cultural Resource Report No. 98-181.

Teague, L.S., 1981. Test Excavations at Painted Rock Reservoir: Sites AZ Z:1:7, AZ Z:1:8 and AZ S:16:36 Archaeological Series No. 143 Arizona State Museum, Tucson.

Thurtle, M.C. (Ed.), 2001. The Cultural Landscape of Okie Hill: An Archaeological Survey of 5,355 Acres on the North Tactical Range of the Barry M. Goldwater Range in Southwestern Arizona. SWCA Environmental Consultants, Tucson SWCA Cultural Resource Report No. 99-205.

Tucker, D.B. (Ed.), 2000. Footsteps on the Bajada, Volume II: An Archaeological Survey of 15,813 Acres on the North Tactical Range of the Barry M. Goldwater Air Force Range in Southwestern Arizona. SWCA Environmental Consultants, Tucson SWCA Cultural Resource Report No. 99-140.

Vivian, R.G., 1965. An archaeological survey of the lower Gila River, Arizona. The Kiva 30 95-146.

Wasley, W.W., Johnson, A.E., 1965. Salvage Archaeology in Painted Rocks Reservoir, Western Reservoir. Anthropological Papers of the University of Arizona Number 9. The University of Arizona Press, Tucson.

Waters, M.R., 1982a. The Lowland Patayan ceramic tradition. In: McGuire, R.H., Schiffer, M.B. (Eds.), Hohokam and Patayan: Prehistory of Southwestern Arizona. Academic Press, New York, pp. 275-297.

Waters, M.R., 1982b. The Lowland Patayan ceramic typology. In: McGuire, R.H., Schiffer M.B. (Eds.), Hohokam and Patayan: Prehistory of Southwestern Arizona. Academic Press, New York, pp. 537-570.

Yablon, R.K., 1978. Archaeological Investigations of the Vaiva Vo-Kotahk Road Project Papago Indian Reservation. M.A. thesis Department of Anthropology, Arizona State University, Tempe. 